Piotr Gontarczyk

\title{
W sprawie „Przyczynku do historii PPR” autorstwa Grzegorza Motyki
}

Z opóźnieniem reaguję na „Przyczynek do historii PPR. Na marginesie książki Piotra Gontarczyka Polska Partia Robotnicza. Droga do wtadzy (1941-1944)” pióra dr. Grzegorza Motyki opublikowany w „Zagładzie Żydów” (t. 4/2008 r.). Wspomniany autor napisał coś w rodzaju recenzji mojej książki o PPR, w której zgłosił do niej szereg zastrzeżeń. Są to uwagi generalne, dotyczące ważkich spraw politycznych polskiego podziemia, ale przede wszystkim sprawy związane $\mathrm{z}$ działalnością Gwardii Ludowej i Armii Ludowej. Marginalnie odnosi się autor do głównego tematu pracy, historii Polskiej Partii Robotniczej. Sam fakt zainteresowania książką cieszy, jednak ze względu na wątpliwą trafność wielu uwag wspomnianego „Przyczynku...” czuję się $\mathrm{w}$ obowiązku z jego treścią polemizować. Z konieczności nie mogę odnieść się do wszystkich wątków, poprzestając na rzeczach najważniejszych i najbardziej typowych.

Jeden z pierwszych zarzutów, jakie mi postawiono w „Przyczynku...”, to rzekome podanie błędnych informacji na temat sytuacji narodowościowej na Kresach Wschodnich. Miał to być dowód na to, że „merytoryczne potknięcia” widać u mnie „gołym okiem: Autor zdecydowanie za Matym rocznikiem statystycznym z 1939 r. twierdzi, iż Polacy stanowili większość ludności w pięciu z ośmiu województw kresowych. Nie trzeba [...] znać bogatej literatury analizującej przekłamania przedwojennej statystyki, lecz zwyczajnie sięgnąć po dobry podręcznik, by się dowiedzieć, że w istocie byli większością jedynie w województwie wileńskim" (s. 581-582). Z zakłopotaniem muszę stwierdzić, że w mojej książce nigdzie nie twierdzę, że Polacy stanowili we wspomnianych województwach „większość”. W rzeczywistości napisałem wyraźnie, że w pięciu z ośmiu wspomnianych województw ludność polska była „najliczniejszą grupą narodowościową” (s. 60), a to chyba coś innego. W tym świetle wstępne słowa Motyki, że w mojej książce błędy widać „gołym okiem”, nabierają dość szczególnego wymiaru. Czy nie należało, przed lekturą, owego "gołego oka” czymś solidnym uzbroić? Autor myli się również, twierdząc, że tylko w jednym $z$ ośmiu wspomnianych przeze mnie województw Polacy byli w większości. Co do - na przykład - województwa białostockiego (około 67\% Polaków), chyba lepiej byłoby, gdyby sam zapoznał się $\mathrm{z}$ zalecaną innym literaturą przedmiotu. 
Po powyższych wywodach autor „Przyczynku...” pisze: „ta demograficzna wzmianka jest zresztą jednym z nielicznym miejsc, gdzie w ogóle w recenzowanej pracy występują ziemie wschodnie II Rzeczypospolitej. Jeśliby przyjąć styl polemiki uprawianej przez Gontarczyka, to wręcz można mu zarzucić przyjęcie peerelowskiej optyki nakazującej pomijać historię Kresów. W książce nie znajdziemy zatem informacji o działalności w międzywojennej Polsce Komunistycznej Partii Zachodniej Ukrainy i Komunistycznej Partii Zachodniej Białorusi, bądź co bądź części składowych KPP. Dosłownie jednym zdaniem są skwitowane komunistyczne dywersje we wrześniu 1939 r., ściśle związane z inwazją ZSRR na Polskę i nierzadko przyjmujące charakter lokalnych buntów" (s. 582). Uprzejmie przypominam, że tytuł recenzowanej książki brzmi następująco: Polska Partia Robotnicza. Droga do władzy 1941-1944. W związku z powyższym poza obszarem badawczym były te ziemie, na których nie działała konspiracyjna PPR. Piszę w książce wyraźnie, że kierownictwo tej partii uważało Kresy Wschodnie po prostu za tereny Związku Sowieckiego i nie podejmowało tam działalności (s. 70-71) ${ }^{1}$. Z tego punktu widzenia stawiany mi przez Motykę zarzut przyjęcia „peerelowskiej optyki nakazującej pomijać historię Kresów" (s. 582) brzmi niezbyt poważnie. Ponadto wyjaśniam (znowu: polecam tytuł książki), że nie jest to opracowanie dotyczące przedwojennego ruchu komunistycznego, KPP, KPZU, KPZB, ani Narodowych Sił Zbrojnych, ani monografia losów jeńców sowieckich w czasie II wojny światowej. Nie jest to także opracowanie dotyczące działań komunistów na Kresach Wschodnich w 1939 r., bowiem ramy chronologicznie pracy (także znajdujące się w tytule książki) wskazują, że historia Polskiej Partii Robotniczej zaczęła się w 1941 r. Naturalnie, omawiam i wątki wcześniejsze, ale mogę tu dokonywać niezbędnego wyboru. Także inne kwestie: takie jak KPP, KPZU, KPZB, NSZ, jeńcy sowieccy, a nawet historia GL-AL są dla mnie istotne przede wszystkim o tyle, o ile są mi potrzebne do przedstawienia historii PPR.

Z ubolewaniem stwierdzam, że powyższy wywód wystarczy za komentarz do znakomitej większości stawianych przez Motykę zarzutów. Inna rzecz, że znaczna część z nich budzi oczywiste wątpliwości. Na przykład ten dotyczący interpretacji jednego z rozkazów dowództwa NSZ i rzekomego zabicia trzech Żydów przez żołnierzy tej formacji w 1944 r.: „Według Gontarczyka rozkaz NSZ z 1 grudnia 1942 r. nakazujący likwidować »bandy« złożone np. ze zbiegłych jeńców czy Żydów dotyczył wyłącznie elementu kryminalnego. Tymczasem przytoczony wyżej fragment eneszetowskiej kroniki [Brygady Świętokrzyskiej NSZ] udowadnia, iż wcale nie jest to tak oczywiste" (s. 586). Autor tych słów nie wskazał na bezpośredni związek między wspomnianym przez siebie wydarzeniem z października $1944 \mathrm{r}$. a rozkazem NSZ z grudnia 1942. Co dużo ważniejsze: nie ma on nawet dowodu, że wspomnianych Żydów rzeczywiście spotkało coś złego. A twierdzenia Motyki pod tytułem: „nie ulega wątpliwości, że jest niezwykle mało prawdopodobne”, że było inaczej (s. 585), nie brzmią zbyt wiarygodnie. Co ciekawe, ten niewyjaśniony prze-

${ }^{1}$ O przypadku struktur PPR we Lwowie, które powstały samorzutnie i których KC PPR chciała się po prostu pozbyć, wspominam na marginesie. 
cież incydent jest dla autora „Przyczynku...” wystarczający, żeby postawić problem „zabójstw popełnionych [przez NSZ] na Żydach w ramach akcji zwalczania wpływów komunistycznych” (s. 585). Zabawne, że to o mnie Motyka pisze: „[autor] posuwa się do granic manipulacji” (s. 583).

W tekście „Przyczynku...” jest jednak kilka spraw poważniejszych: „O Robercie Satanowskim, organizatorze i dowódcy polskiej komunistycznej partyzantki na Wołyniu, [Gontarczyk] wspomina tylko, że był »sowieckim partyzantem«, co nawet biorąc pod uwagę jego podporządkowanie Ukraińskiemu Sztabowi Ruchu Partyzanckiego jest uproszczeniem” (s. 582). Podtrzymuję to, co napisałem, a fakty podane przez Motykę moje słowa tylko potwierdzają. Nadto mój krytyk nie napisał, na czym polega to moje „uproszczenie”, toteż nie bardzo jest o czym dyskutować. Dalej autor „Przyczynku...” pisze: „cytowany przez Gontarczyka memoriał szefa Centralnego Sztabu Ruchu Partyzanckiego Pantelejmona Ponomarienki, w którym ten proponuje wysłanie do Polski kilkudziesięciu agentów w celu wywołania wojny partyzanckiej, nie odnosi się - wbrew temu, co pisze autor - do PPR, lecz najpewniej właśnie do partyzantów Satanowskiego” (s. 582).

Ów sporny dokument traktuje o generalnych postulatach dotyczących rozwiązywania spraw polskich. Ponomarienko proponował, by w Polsce rozpętać masową akcję partyzancką, która osłabiłaby Niemców, ale przede wszystkim wyniszczyła Polaków. Nadto pisze on o „wykorzystaniu antyniemieckich nastrojów ludności polskiej na terytorium Polski”, co jasno wskazuje, że chodzi o Polskę centralną, a nie ziemie uznawane przez Sowietów za Zachodnią Ukrainę i Zachodnią Białoruś. Nie ma więc żadnych podstaw, by łączyć memoriał Ponomarienki z grupą Satanowskiego działającą na Wołyniu. A to, co napisał w tej sprawie Motyka - poniekąd naukowiec specjalizujący się w tej dokładnie tematyce, bo przecież nie w PPR - to nonsens. Jednak na zakończenie swoich wywodów autor „Przyczynku...” twierdzi stanowczo, że treść omawianego memoriału jednoznacznie rozstrzyga, że chodziło o grupę Satanowskiego: „wskazuje na to niezbicie zakończenie tego dokumentu, już przez Gontarczyka nie przywoływane” (s. 582). Czytelnik niniejszej polemiki może wiarygodność słów Motyki zweryfikować, bowiem wspomniany dokument ze stycznia 1943 r. został kilka lat temu przetłumaczony na język polski i opublikowany w periodyku „Pamięć i Sprawiedliwość” przez dr. Bogdana Musiała². Kto jak kto, ale Grzegorz Motyka powinien o tym wiedzieć. Lektura wspomnianego dokumentu wskazuje, że twierdzenia zawarte w „Przyczynku...” nie mają potwierdzenia w faktach.

Sporo miejsca poświęca autor sprawie śmierci Ludwika Widerszala i Jerzego Makowieckiego, choć to też dla mnie kwestia całkiem drugorzędna. Główny argument Motyki, który głosi, że „znawcy tej problematyki nie mają [...] wątpliwości, że inspiratorów zabójstw należy szukać w środowisku skrajnej prawicy” (s. 587), nie przekonuje. W nauce bowiem ważne jest przede wszystkim, co zostało napisa-

${ }^{2}$ B. Musiał, Memoriat Pantelejmona Ponomarienki z 20 stycznia 1943 r. „O zachowaniu się Polaków i niektórych naszych zadaniach”, „Pamięć i Sprawiedliwość” 2006, nr 1, s. 379-385. 
nie i czym udokumentowane, a nie kto to napisał. Za dużo wokół tej kwestii było politycznych machinacji, swoiście pojmowanej troski o „dobre imię AK”, politycznych czy wręcz środowiskowych interesów. Wolałbym więc, żeby w tym wypadku zamiast powoływania się na innych Motyka pokazał jakieś dowody. Skoro „znawcy problematyki" solidnie rzecz udokumentowali, to chyba nie będzie z tym kłopotu, prawda? Póki co, podobne odwołania traktuję jako brak rzeczowych argumentów. Taką samą wartość ma opieranie się autora „Przyczynku...” na słowach gen. Bora-Komorowskiego, który także po latach za śmierć Widerszala i Makowieckiego obarczał działaczy obozu narodowego. Kłania się krytyka źródła historycznego: w książce gen. Komorowskiego jest więcej twierdzeń wątpliwych czy w sposób oczywisty nieprawdziwych, których nie sposób tutaj wyliczać i cytować.

Równie trudno odnieść się tu kompleksowo do uwag Motyki w sprawie „wpadki” komunistycznej drukarni spowodowanej donosem do gestapo, który wysłało kierownictwo PPR. Autor „Przyczynku...” pisze: „Gontarczyk w oparciu o akta śledcze przedstawia dwie wersje możliwych wydarzeń i nie bardzo wiadomo, za którą się opowiada. W tekście głównym zdecydowanie pisze o "zadenuncjowaniu« drukarni GL przez Spychalskiego, który miał wydać ją gestapo, błędnie sądząc, że należy ona do AK. Z kolei w przypisie [...] zdaje się przychylać do wersji, iż peperowcy wydali Niemcom drukarnię polskiej organizacji niepodległościowej przy ul. Twardej, a drukarnia przy ul. Grzybowskiej wpadła przypadkiem podczas prowadzonej obławy" (s. 583). Motyka będzie musiał mi wybaczyć ostre porównanie, ale jego wywody o mojej książce przypominają nieco „Radio Erewań”: nie powołuję się wyłącznie na materiały śledcze - opisując sprawę drukarni na Grzybowskiej, wyraźnie piszę również o „działaniach operacyjnych podjętych przez aparat bezpieczeństwa” (s. 206); nie ma u mnie słowa o tym, że „zasypana” przez komunistów drukarnia należała do Armii Krajowej; nie piszę też o drukarni GL - jest za to drukarnia PPR; wiadomo również, za którą wersją się opowiadam; nieprawdą jest twierdzenie, że obie przedstawione w mojej pracy wersje są sprzeczne. Fakt, że na skutek donosu komunistów wpadła polska drukarnia, a potem, w czasie obławy, Niemcy odkryli również lokal PPR, niewiele tu przecież zmienia.

Grzegorz Motyka pisze o mnie dalej: „,Gdyby jeszcze, zamiast polegać na niepewnych dokumentach stworzonych przez funkcjonariuszy X Departamentu, uważniej wczytał się w tak lekceważoną przez siebie literaturę przedmiotu, to zauważyłby, iż drukarnia GL wpadła w lutym 1943 r., a kryjówkę na ul. Twardej komuniści »wsypali« w lutym 1944 r. Związek pomiędzy tymi wydarzeniami istniał tylko w wyobraźni pracowników MBP” (s. 583).

Powtórzę jeszcze raz: drukarnia GL-AL „wpadła” na ulicy Grzybowskiej w lutym 1944 r. na skutek donosu samych komunistów. Nie miało to nic wspólnego z wpadką drukarni „PPR” na tej samej ulicy, która miała miejsce rok wcześniej w lutym 1943 r. Wydarzenia te pomylił w swoich relacjach Józef Światło, a za nim taką wersję powtarzali historycy, w tym i ja. Nie zmienia to jednak faktu, że dla swojego własnego dobra Motyka chyba nie powinien wypowiadać się w kwestii, o której nie ma większego pojęcia i skutkiem tego w jednym krótkim fragmencie 
popełnia tyle błędów. Jego autorytatywne twierdzenie, że związek pomiędzy donosami wysyłanymi przez kierownictwo PPR do gestapo a wpadką komunistycznej drukarni „istniał tylko w wyobraźni pracowników MBP”, ma niewiele wspólnego z rzeczywistością. Co najwyżej ilustruje wątpliwy stan jego wiedzy.

Na zakończenie powyższych wywodów autor „Przyczynku...” pisze: „członkowie PPR faktycznie wysyłali donosy do gestapo, ale wbrew temu, co twierdzi Gontarczyk, już po zerwaniu przez ZSSR [sic!] stosunków dyplomatycznych z Polską” (s. 583). Motyka w całym tekście nadużywa protekcjonalnego tonu i prezentując swoje teorie, za często posługuje się pewnikami. Tym bardziej, że przytoczone wyżej jego stanowcze słowa to konfabulacje niepoparte naukowymi argumentami ${ }^{3}$.

Niekiedy uwagi autora „Przyczynku...” są tak dalekie od historii i treści omawianej pracy, że przecierałem oczy ze zdumienia. Grzegorz Motyka twierdzi, że poszukiwałem argumentów (a raczej je tworzyłem) do tego, żeby kierownictwo PPR „oskarżyć nawet o zdradę” (s. 583). Toż to przecież nonsens kompletny. W całej książce opisującej genezę i działania PPR bez przerwy prezentuję pogląd, że kierownictwo tej partii działało na zlecenie i na rzecz Związku Sowieckiego, a jej aktywność godziła w najbardziej żywotne interesy polskiego społeczeństwa. Więc po co miałbym w sprawie PPR, stanowiącej naczynie połączone z Kominternem i NKWD, szukać argumentów wystarczających do „oskarżenia nawet o zdradę”? A kogo ta sowiecka agentura miałaby zdradzać? Kolejnych wywodów autora nie sposób nie komentować z uśmiechem. Tak jak tych dotyczących akcji NSZ pod Borowem, w wyniku której w 1943 r. rozstrzelano niemal wszystkich członków komunistycznej grupy Stefana Skrzypka „Słowika”. Cała krytyka przedstawionego przeze mnie scenariusza wydarzeń świadczy o braku znajomości realiów funkcjonowania niepodległościowej partyzantki, po czym na koniec pada twierdzenie: „Gontarczyk nie widzi nic złego w poczynaniach NSZ w Borowie” (s. 586). Ależ oczywiście, że widzę. A nawet jestem krytyczny. Nie rozumiem, jak można było dopuścić od tego, żeby dwóch spośród rozstrzeliwanych uciekło.

Jednym z ciekawszych fragmentów tekstu Motyki jest krytyka mojego twierdzenia, że polskie podziemie niepodległościowe powinno było podjąć zdecydowaną, siłową akcję antykomunistyczną. Recenzent uważa, że byłaby ona niecelowa: „tego typu operacja nie przyniosłaby nic, poza zwiększeniem liczby ofiar. Tak czy inaczej Stalin zainstalowałby w Polsce rząd komunistyczny, wszak nawet PKWN [...] opierał się nie na partyzantach AL, lecz bagnetach Armii Czerwonej i NKWD. Polityka AK, a potem WiN, mimo różnych błędów i niekonsekwencji, pozwalając przynajmniej minimalizować straty, była w ówczesnej sytuacji zdecydowanie bardziej racjonalna niż ta, którą prowadziły NSZ” (s. 587).

${ }^{3}$ W najbliższym czasie przygotuję tekst, w którym szczegółowo odniosę się do całej sprawy. W związku z powyższym, niejako uprzedzając odpowiedź dr. Motyki, jak najżyczliwiej przestrzegam go przed powoływaniem się na ostatnie ustalenia Janusza Marszalca, bowiem są one merytorycznie wątpliwe. 
Mam nadzieję, że na ten temat będę miał kiedyś z Grzegorzem Motyką zaszczyt podyskutować. Na razie stwierdzę tylko, iż nie podzielam jego opinii, że taka akcja „nie przyniosłaby nic”, a w książce przytaczam na to konkretne argumenty. Chodziło mi nie o możliwość obrony niepodległości, tylko o to, że likwidacja komunistycznej partyzantki znacząco wpłynęłaby na bezpieczeństwo polskiego podziemia niepodległościowego, ludności cywilnej, a także utrudniłaby rozpracowanie polskiego podziemia niepodległościowego przez UB i NKWD. Autor „Przyczynku...” nie ustosunkował się do moich argumentów, więc jego krytyka jest nieco gołosłowna. Nie przekonuje mnie również twierdzenie, że działania te byłyby niecelowe ze względu na to, że „tak czy inaczej Stalin zainstalowałby w Polsce rząd komunistyczny”. O rzeczy ważne, takie jak niepodległość, czasem warto powalczyć bez względu na to, jak duża istnieje szansa na sukces. Logika racji historycznych przyjęta przez Motykę to silny cios w filozofię działania (nomen omen) Armii Krajowej na Kresach Rzeczypospolitej. Przecież tak czy inaczej Stalin nie oddałby Polsce Wileńszczyzny i Nowogródczyzny. Jaki więc sens miała walka z Sowietami i Litwinami? Czy nie należałoby skupić się na „minimalizowaniu strat” i zdobywaniu wagonów kolejowych na wywiezienie swoich rodzin w okolice Szczecina? O polityce AK, którą Kolega opisuje jako „pozwalającą przynajmniej minimalizować straty, będącą w ówczesnej sytuacji zdecydowanie bardziej racjonalna niż ta, którą prowadziły NSZ”, również będzie trzeba kiedyś podyskutować. Jako punkt wyjścia proponuję Powstanie Warszawskie.

Najsłabszym fragmentem mojej książki jest, zdaniem recenzenta, sposób pisania o partyzantach sowieckich, w znacznej części wywodzących się z byłych sowieckich jeńców. Motyka cytuje moje krytyczne opinie na temat ich „partyzanckiej” działalności, po czym komentuje: „Trudno zauważyć w tych słowach choćby cień współczucia dla osób faktycznie skazanych na śmierć głodową” (s. 584-585).

Co innego niemiecka akcja eksterminacyjna jeńców sowieckich, a co innego brutalny i bezwzględny stosunek Sowietów do polskiej ludności. Nie wiem, czy fakt, że ktoś był byłym jeńcem, którego chcieli zagłodzić Niemcy, usprawiedliwia opisane przeze mnie zachowania. Różnicę pomiędzy moim stanowiskiem a opinią autora „Przyczynku...” widać „gołym okiem”. W sprawie znęcania się nad polską ludnością, gwałtów i rabunków, swoje współczucie adresuję odwrotnie niż mój krytyk. Nie do sprawców, tylko do ofiar.

Podobne wywody mojego krytyka nie zawsze dają miejsce na rzeczową polemikę. Uzupełniają je twierdzenia ogólne niepoparte żadnymi naukowymi argumentami i inwektywy. Autor wcale nie musi się ze mną w tej kwestii zgadzać, ale jeżeli moje opinie o metodologii opisywania konfliktów zbrojnych komunistów i NSZ przez prof. Krystynę Kersten są nietrafne, to trzeba rzeczowo pokazać, że nie mam racji. Tu samo „krzywienie się” nie jest przekonujące. Motyka może również nie podzielać mojej opinii na temat Jana Rzepeckiego. Ale wolałbym, żeby i to wyraził w sposób naukowy. Wbrew temu, co pisze recenzent, nigdy nie odnosiłem się do dorobku naukowego prof. Tomasza Szaroty, bo do takich ocen nie czułem się ani powołany, ani kompetentny. Omawiany przez niego fragment wstępu mojej książki 
dotyczy wyłącznie mocno wątpliwych i źle się kojarzących okoliczności publikacji tekstu Marka Kazimierza Kamińskiego. Sprawę opisałem chyba w sposób nie pozwalający na takie uwagi. Podobnie nigdy nie zarzucałem Koledze Januszowi Marszalcowi prokomunistycznych sympatii. To absurdalne wymysły Grzegorza Motyki. Moje zastrzeżenia dotyczyły jednego z jego artykułów, w którym nadmiernie operował językiem źródeł. Na inne pozanaukowe uwagi autora na temat tego, co myślę, gdzie się zaliczam itd., po prostu szkoda czasu.

Pod koniec „Przyczynku...” autor pozwala sobie na delikatną uszczypliwość: „We wstępie do swojej książki autor skromnie stwierdza: »wydaje się raczej nieprawdopodobne, bym przy tej ilości materiału [...] mógł nie popełnić błędu«. Trudno nie zgodzić się z tą konstatacją” (s. 588). Autor przekręca moje słowa. W istocie w rzeczonym fragmencie napisałem „błędów” - czyli użyłem liczby mnogiej. Nie potrafię stwierdzić, czy moje słowa zniekształcono celowo, by łatwiej było mnie „uszczypnąć” domniemanym brakiem skromności. Ale dopuszczam również, że to skutek cechującej cały tekst nerwowości i niechlujności. Kontrastują one ze swoistym przekonaniem krytyka, że od jego słów tak wiele zależy: „wskazując na słabości pracy Piotra Gontarczyka, nie zamierzam całkowicie przekreślać jej wartości” (s. 588). Kłopot w tym, że w nauce wydawanie tak fundamentalnych ocen jest możliwe po użyciu nieco bardziej rzeczowych uwag, których w „Przyczynku...” nie widać. W przeciwieństwie do oczywistych błędów, braków w wiedzy i skłonności do konfabulacji.

Przyznam szczerze, że Kolegi po prostu nie rozumiem. Dyskusja jest, owszem, ważna, więc o wiele rzeczy chętnie się pospieram. Ale warto przy tym dbać o jakieś proporcje i przysłowiowy fason. Nie czuję się specjalistą od tematów, które Motyka porusza w swoich pracach, toteż nie wpadłbym na pomysł, żeby wydawać cenzurki jego książek i go takim tonem pouczać. Autor „Przyczynku...” oczywiście może uważać się za eksperta od PPR i protekcjonalnym tonem pisać, co „niezbicie” jest prawdą, co „niewątpliwie” napisałem źle i gdzie „niewątpliwie” nie mam racji. Może też coś tam sobie przekreślać czy też „nie przekreślać”. Tylko że po lekturze jego „Przyczynku...” gołym okiem widać, iż w jego przekonaniu o dysponowaniu wystarczającą ku temu wiedzą „niewątpliwie” było sporo przesady. 